\title{
SETTING A RATING SCALE FOR ASSESS Rhizoctonia solani LESIONS ON COTTON, SOYBEAN AND COMMON BEAN SEEDLINGS
}

\author{
AJUSTE DE UMA ESCALA DE NOTAS PARA AVALIAR LESÕES DE \\ Rhizoctonia solani EM PLÂNTULAS DE ALGODÃO, SOJA E FEIJÃO
}

\author{
Augusto César Pereira GOULART \\ Pesquisador M.Sc. Embrapa Agropecuária Oeste, Dourados, MS, Brasil. augusto.goulart@embrapa.br
}

\begin{abstract}
Diseases incited by soilborne fungi are responsible for reducing the yield and cause significant impact to almost all crops. Among then, Rhizoctonia solani AG-4 is considered the most important in the cotton, common bean and soybean crops in Brazil. The use of diagrammatic scale or rating scales, as a tool to help in the quantification of the severity of a particular disease, is more common for foliar diseases. Considering the lack of a standardized, illustrated and easy-to-apply methodology for assessing the severity of $R$. solani lesions in cotton, soybean and common bean seedlings, a simple and precise rating scale was developed with the objective to fill this gap. The proposed scale shows four levels of disease severity, with the descriptions and illustrations for each type of lesion observed in the cotton, soybean and common bean seedlings. This developed scale was validated in many experiments and proved to be adequate for severity assessments of $R$. solani lesions on cotton, soybean and common bean seedlings.
\end{abstract}

KEYWORDS: Lesion severity. Soilborne pathogen. Damping-off.

Diseases incited by soilborne fungi are responsible for reducing the yield and cause significant impact to almost all crops. However, those that occur in the early stage of seedling development are considered a major problem worldwide (GOLL et al., 2013; ZEUN et al., 2013). When the conditions in the field are favorable to its occurrence, the losses in the stand and, consequently, in the grain yield, can be significant (RIZVI e YANG, 1996). In general, the damages at this crop stage are related to the reduction of seedling population. Damping-off occurs when germinating seedlings are infected prior to or just after emergence. This pathogen causes both, preemergence damping-off (rotting the seeds before and soon after germination) and post-emergence damping-off (causing the death of the seedlings newly emerged) as well as foliar blight and also stem and root rot (DORRANCE et al., 2003; GOULART, 2007a, 2007b, 2010; MALVICK, 2017; RIZVI; YANG, 1996).

Based on importance, pathogenicity, occurrence and damages criteria, the soilborne pathogen Rhizoctonia solani Kuhn anastomosis group (AG)-4 (teleomorf: Thanatephorus cucumeris (A.B. Frank) Donk) is considered the most important in the cotton, common bean and soybean crops in Brazil (GOULART, 2005; 2010). This importance is related to its frequency of occurrence, predominance in the majority of the soils and in different environmental conditions and, consequently, the damages that causes in the early stage of crop establishment (BIANCHINI et al.,
1997; GOULART, 2007b, 2016; SARTORATO et al., 1987).

Pathogen such $R$. solani has a wide host range; it is non-specialized and polyphagous pathogen or generalist. Damage caused by this pathogen may occur at any time during the growing season, but it is more severe on young seedlings (GOULART, 2010; 2016). Symptoms vary according to the host and the plant part affected. Seedling damping-off is probably the most common disease caused by $R$. solani. This pathogen also can cause seed rot, root rot, and lesions on hypocotyls. On hypocotyls, lesions are reddish-brown and sunken. Diseased seedlings collapse from the firm, dry canker that girdles the hypocotyl (GOULART, 2017b; 2016; ZAMBOLIM et al., 1997; HARPER, 2012). Damping-off usually occurs in a period from pre-emergence and 10 to 15 days after seedling emergence (GOULART, 2010; 2016). In adult plants, the symptoms of $R$. solani are dry root rot, sunken cankers, reddish, circular to elongated and brown lesions at the base of the stem, below and at ground level. The disease may progress, causing damping-off, wilting or temporary survival of the plants with presence of adventitious roots above of the affected region (GOULART, 2007b; HARPER, 2012).

Despite the improved control of this disease, losses are significant. Results obtained in the USA by Tachibana (1968), cited by Dorrance et al. (2003), showed that $R$. solani caused a loss of $50 \%$ in soybean grain yield. In Canada, studies have shown that $R$. solani caused a loss of $48 \%$ in stand establishment and $52 \%$ in seed yield in soybean 
(CHANG et al., 2018) According to McLean and Gazaway (2000), in the USA, in 1995, the reduction of cotton yield due to early-season diseases has been estimated in 180,000 tons, representing loss of $2.8 \%$ per year. In common bean, yield losses ranged from $10 \%$ to $60 \%$, when $R$. solani acts as a complex with other soil pathogens (ZAMBOLIM et al., 1997). This survey has not been done yet in Brazil, considering soybean, cotton and common bean crops.

In plant disease experiments, individuals of each experimental unit are commonly classified, such as leaves, branches, fruits, flowers, according to categories of a discrete quantitative scale, corresponding to ranges of disease severity (CZERMAINSKI, 1999). In general, this classification occurs through visual assessment and results in the counting of elements or incidence by class.

The simple observation of the occurrence of a particular disease, its incidence and even severity quantification using subjective criteria (visual assessment) in most cases may lead to error, requiring the adoption of objective criteria for quantifying (AMORIM, 1995; LENZ et al., 2009). Several strategies have been proposed to quantify the severity of disease accurately. Among them, there are the diagrammatic scale or rating scales, which are illustrated representations of parts of the plant to be assessed, with symptoms of different severity levels (AMORIM, 1995; BERGAMIN FILHO e AMORIM, 1996). These scales should present a standard symptomatology, comparable to those observed under natural conditions of infection or even produced through inoculation. Thus, the use of correctly elaborated diagrammatic scales can reduce the subjectivity of severity estimates, improving the accuracy and precision of the evaluation, being the main severity assessment tool for many diseases (AQUINO et al., 2008; LENZ et al., 2009; MARTINS et al., 2004). However, it should be taken into account that the diagrammatic scales should be easy to use, applicable in different conditions, as well as provide sufficient information that represent all stages of disease development (BERGAMIN FILHO e AMORIM, 1996).

The use of diagrammatic scale or rating scales, as a tool to help in the quantification of the severity of a particular disease, is more common for foliar diseases. In relation to soilborne fungi, and specifically regarding to $R$. solani, two references were found about the subject, in the patosystem common bean $\mathrm{x} R$. solani root rot (RODRIGUES et al., 1999; VAN SCHOONHOVEN and PASTORCORRALES, 1987). It should be noted that in only one of these publications, illustrations of parts of plants with symptoms at different severity levels were available, as suggested by Amorim (1995) and Bergamin Filho and Amorim (1996). For soybean and cotton crops, no reference about this subject has been found.

In experiments of fungicides seed treatment and germplasm evaluating reaction to Rhizoctonia solani soilborne, in the seedling stage, the most common is the determination of seedling dampingoff. In the remaining seedlings, only the presence of pathogen lesions in the roots and in the hypocotyl is measured (disease incidence $=$ percentage of infected seedlings in a sample or population). The disease severity, which is estimated on the basis of tissue area covered by the symptoms, is not often considered, due to the lack of adequate and standardized visual methodology to estimate it in a safe way. Providing real images of different types of $R$. solani lesions on cotton, soybean and common bean seedlings, instead of drawings, for example, increases the accuracy of the evaluation. Photos are of practical use, unlike textual descriptions that may have different degrees of subjectivity and interpretation. Many experiments were carried out at Embrapa Western Agriculture, Dourados, MS, Brazil, in order to validate this rating scale, which proved to be adequate for severity assessments of $\mathrm{R}$. solani lesions on cotton, soybean and common bean seedlings. In addition, the results obtained were also used to calculate the disease index (severity), in the remaining seedlings, according to McKinney formula (McKinney, 1923)).

Considering the lack of a standardized, illustrated and easy-to-apply methodology for assessing the severity of $R$. solani lesions in cotton, soybean and common bean seedlings, a simple and precise rating scale was developed with the objective to fill this gap.

\section{Rating Scale}

A rating scale with four levels of disease severity ( 0 a 3$)$, according to type of lesions observed in the cotton, soybean and common bean seedlings, was developed and validated. Figures 1, 2 and 3 show the descriptions and illustrations for each type of lesion, its respective score and the corresponding crop. 


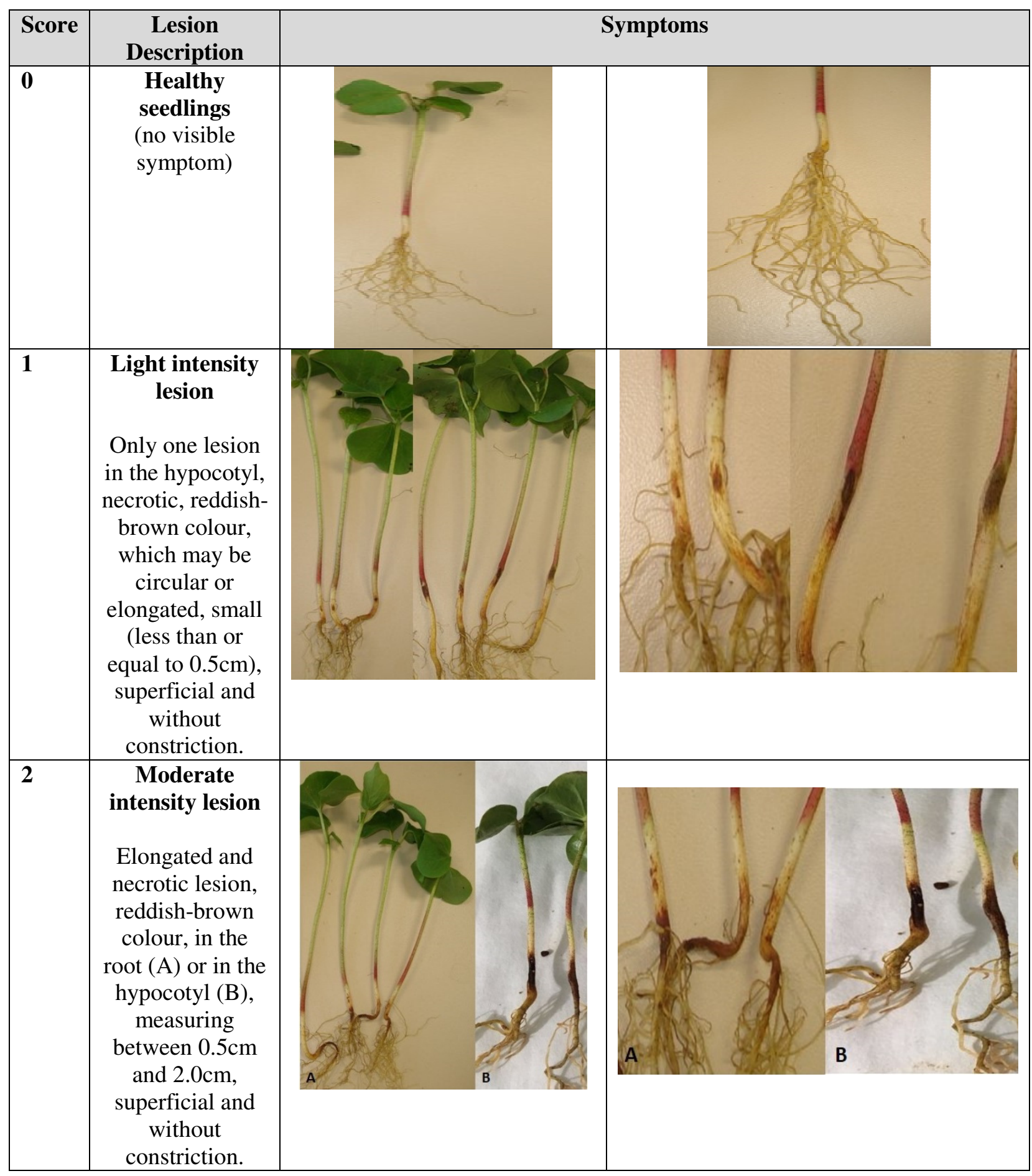




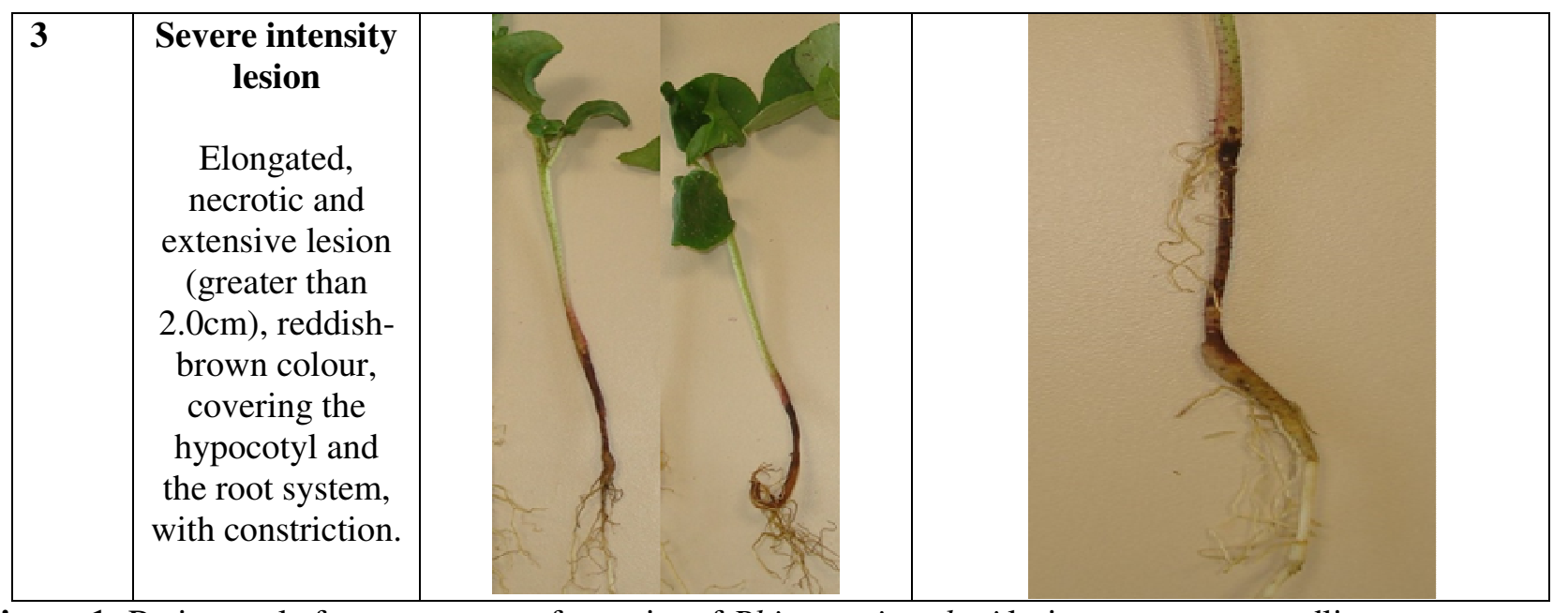

Figure 1: Rating scale for assessment of severity of Rhizoctonia solani lesions on cotton seedlings

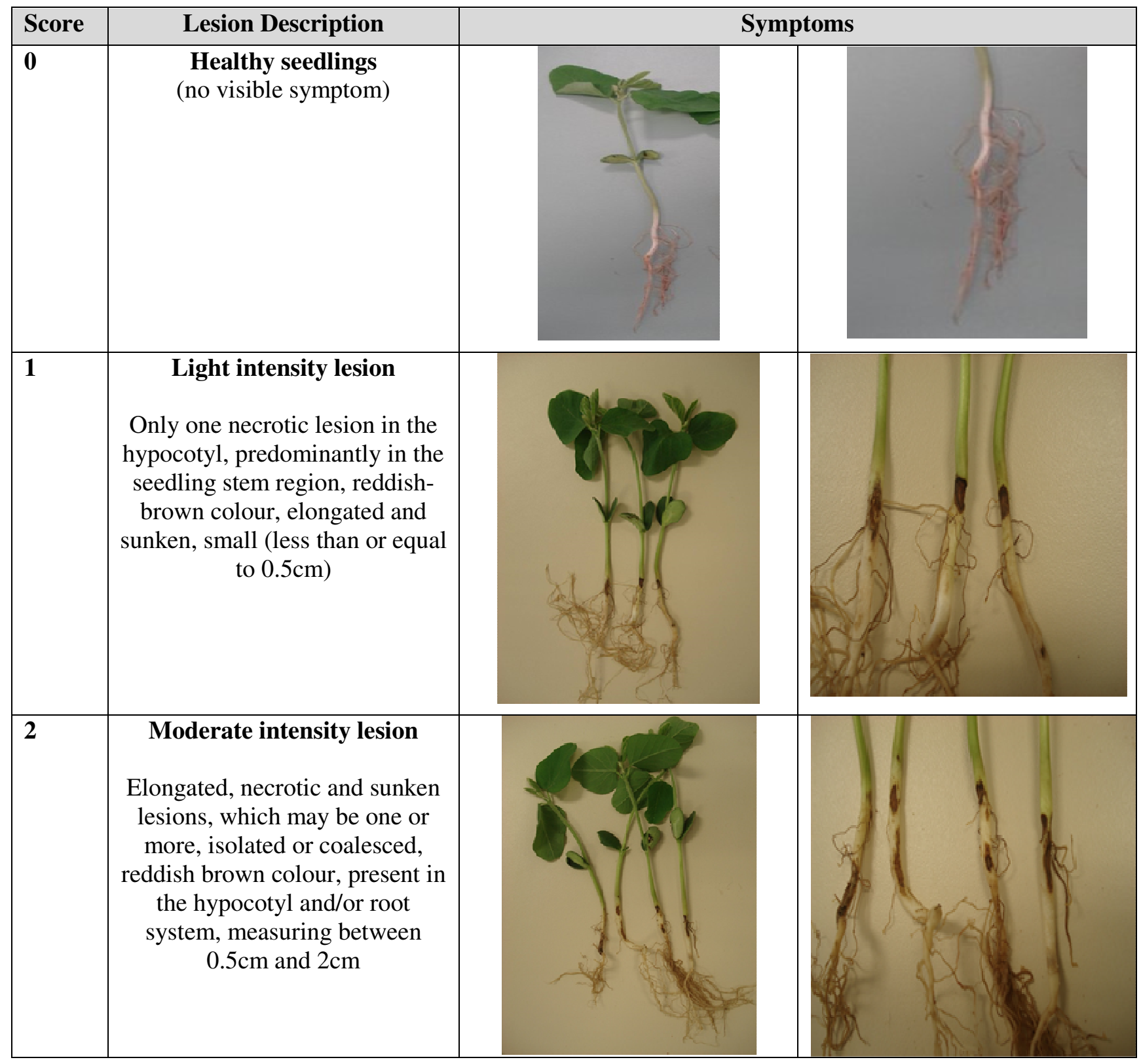




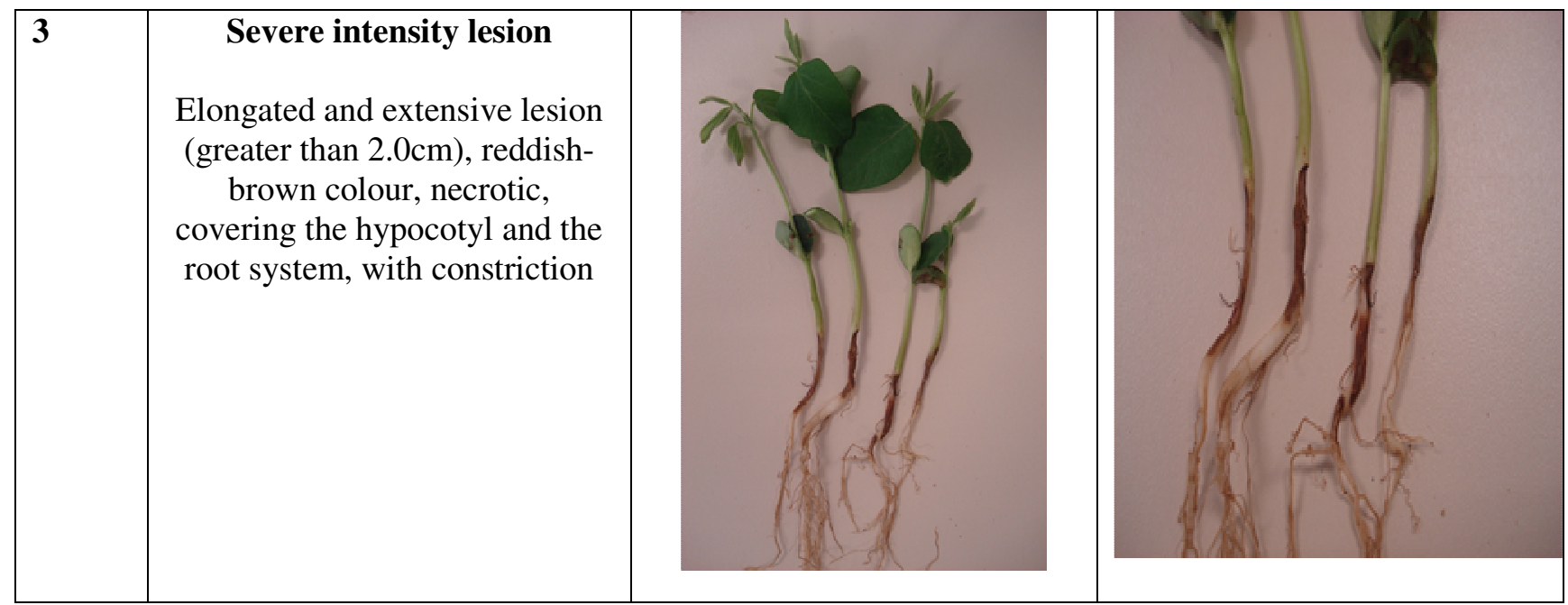

Figure 2: Rating scale for assessment of severity of Rhizoctonia solani lesions on soybean seedlings.

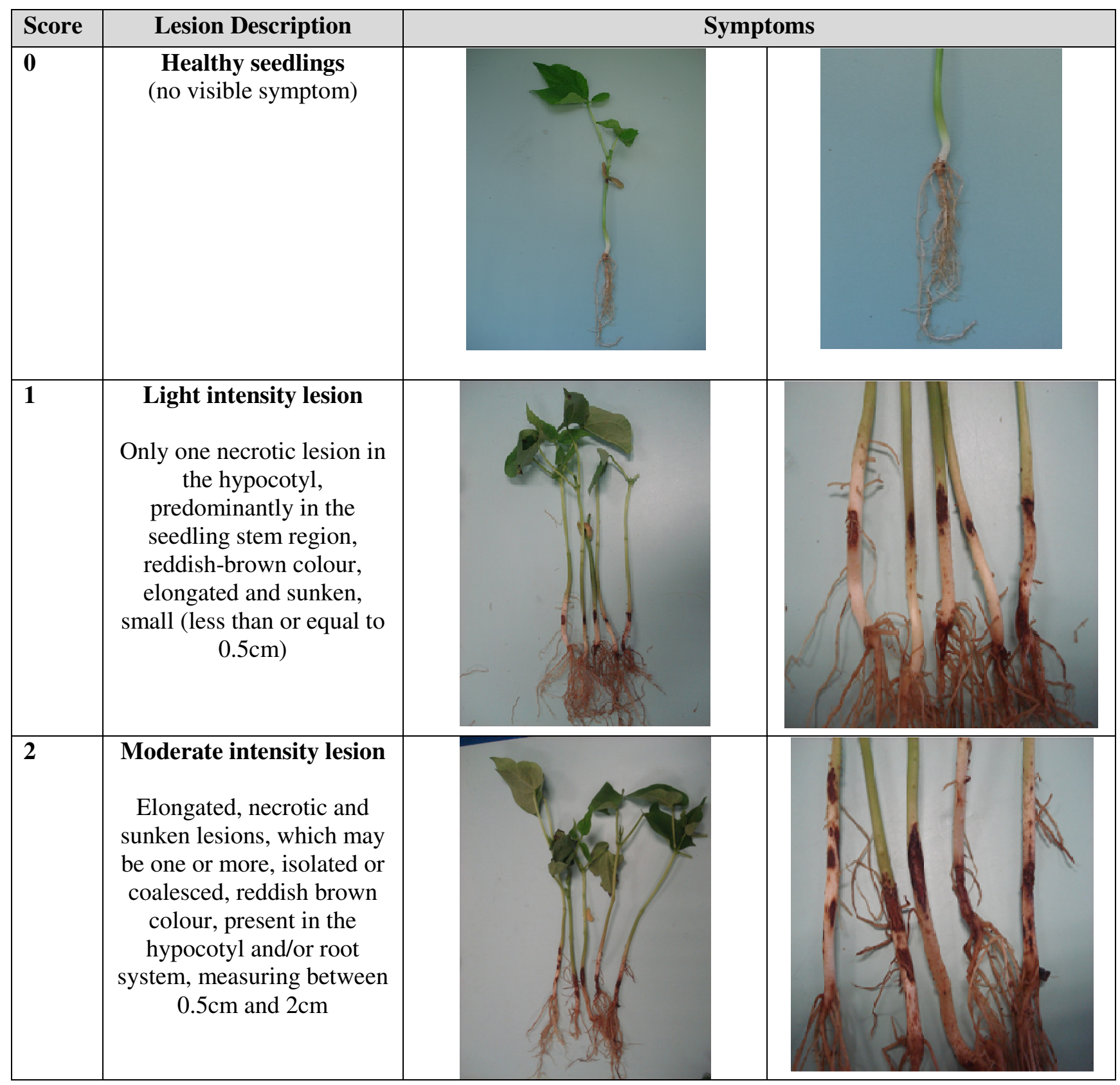




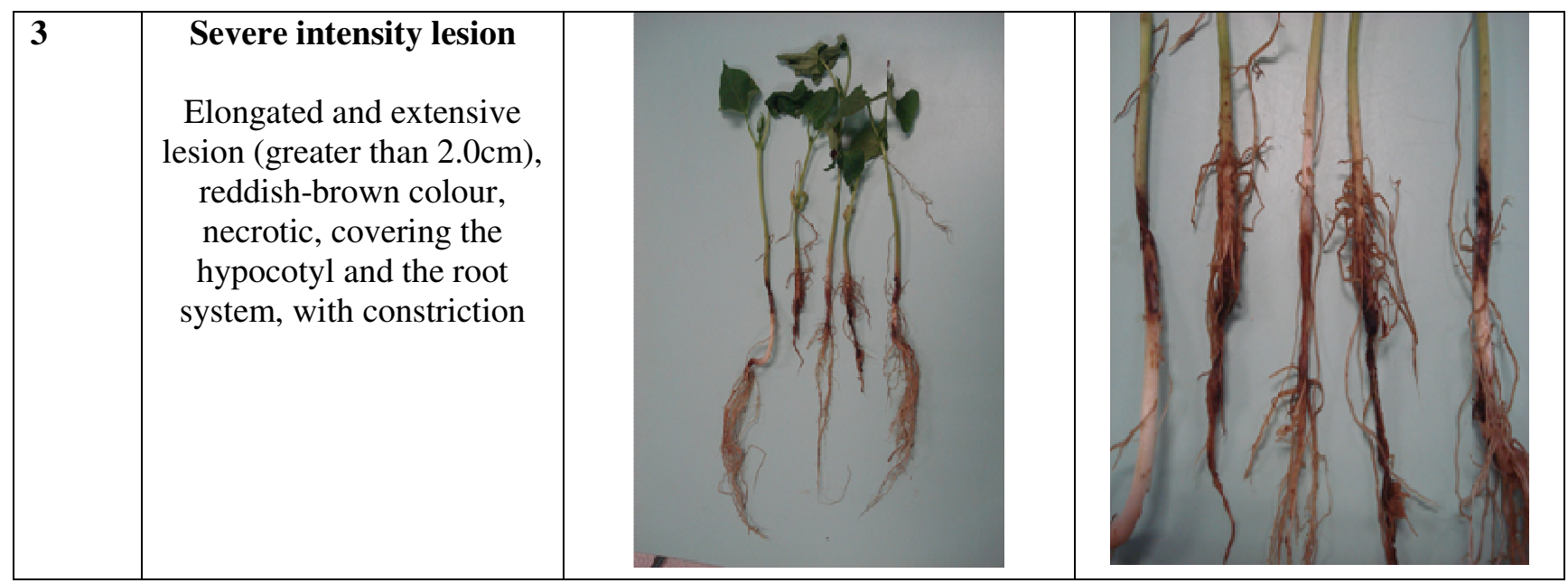

Figure 3: Rating scale for assessment of severity of Rhizoctonia solani lesions on common bean seedlings.

RESUMO: Doenças causadas por fungos de solo reduzem a produtividade e impactam de forma significativa quase todas as culturas. Dentre elas, Rhizoctonia solani AG-4 é considerada a mais importante nas culturas de algodão, feijão e soja no Brasil. A utilização de escalas diagramáticas ou escalas de notas, como ferramenta para auxiliar na quantificação da severidade de uma determinada doença, é mais comum quando se trata de doenças foliares. Considerando a inexistência, até então, de metodologia padronizada, ilustrada e de fácil aplicação para a avaliação da severidade de lesões de $R$. solani em plântulas de algodão, soja e feijão, desenvolveu-se uma escala de notas, simples e precisa, com o objetivo de suprir essa lacuna. A escala proposta apresenta quatro níveis de severidade de doença, com descrições e ilustrações para cada tipo de lesão observada nas plântulas de algodão, soja e feijão. Essa escala foi validade em inúmeros experimentos, provando ser adequada para a avaliação da severidade de lesões de $R$. solani nas plântulas de algodão, soja e feijão.

PALAVRAS-CHAVE: Severidade de lesão. Patógeno habitante do solo. Damping-off

\section{REFERENCES}

AMORIM, L. Avaliação de doenças. In: BERGAMIN FILHO, A.; KIMATI, H.; AMORIM, L. (Ed.). Manual de fitopatologia: princípios e conceitos. 3.ed. São Paulo: Ceres, 1995. v. 1, p. 647-671.

AQUINO, L. A. et al. Elaboração e validação de escala diagramática para quantificação da mancha de ramularia do algodoeiro. Summa Phytopathologica, v. 34, n. 4, p. 361-363, 2008. Disponível em: <http://www.scielo.br/pdf/sp/v34n4/v34n4a12>. https://doi.org/10.1590/S0100-54052008000400012

BERGAMIN FILHO, A.; AMORIM, L. Doenças de plantas tropicais: epidemiologia e controle econômico. São Paulo: Agronômica Ceres, 1996. 299p.

BIANCHINI, A.; MARINGONI, A. C.; CARNEIRO, S. M. T. P. G. Doenças do feijoeiro. In: KIMATIM, H.; AMORIM, L.; BERGAMIN FILHO, A.; CAMARGO, L. E. A.; REZENDE, J. A. M.(Ed.). Manual de fitopatologia: doenças das plantas cultivadas. 3. ed. São Paulo: Agronômica Ceres, 1997.v. 2, p. 376-399.

CHANG, K. F.; HWANG, S. F.; AHMED, H. U.; STRELKOV, S.E.; HARDING, M. W.; CONNER, R. L.; MCLAREN, D. L.; GOSSEN, B. D.; TURNBULL, G. D. Disease reaction to Rhizoctonia solani and yield losses in soybean. Canadian Journal of Plant Science, 2018, 98(1): 115-124, https://doi.org/10.1139/CJPS2017-0053

CZERMAINSKI, A. B. C. Generalização de um índice de intensidade de infecção em experimentos de avaliação de doenças em plantas. Pesquisa Agropecuária Brasileira, v. 34, n. 9, p. 1545-1555, set. 1999. https://doi.org/10.1590/S0100-204X1999000900004 
DORRANCE, A. E.; KLEINHENZ, M. D.; MCCLURE, S.A.; TUTTLE, N.T. Temperature, moisture, and seed treatment effects on Rhizoctonia solani root rot of soybean. Plant Disease, v.87, n. 5, p. 533-538, May 2003. https://doi.org/10.1094/PDIS.2003.87.5.533

GOLL, M. B.; SCHADE-SCHÜTZE; A.; SWART, G.; OOSTENDORP, M.; SCHOTT, J. J.; JASER, B.; FELSENSTEIN, F. G. Survey on the prevalence of Rhizoctonia spp. in European soils and determination of the baseline sensitivity towards sedaxane. Plant Pathology, v. 63, n; 1, p. 148-154, Feb. 2014. https://doi.org/10.1111/ppa.12063

GOULART, A.C.P. Tratamento de sementes de soja com fungicidas. In: ZAMBOLIM, L. (Ed.). Sementes: qualidade fitossanitária. Viçosa, MG: UFV, DFP, 2005. p. 451-478.

GOULART, A. C. P. Soja: tratamento de sementes: semente blindada. Cultivar: grandes culturas, ano 9, n. 98, jul. 2007a. Caderno Técnico Cultivar, p.08-11, jul. 2007a. Encarte.

GOULART, A. C. P. Soja e algodão: proteção na origem. Cultivar: grandes culturas, ano 9, n. 101, p.26-28, out. 2007b.

GOULART, A. C.P. Soja: hora de tratar. Cultivar: grandes culturas, ano 12, n. 135, p. 22-25, ago. 2010.

GOULART, A. C. P. Reação de cultivares de algodoeiro a Rhizoctonia solani na fase de plântula e benefícios do tratamento de sementes com fungicidas. Summa Phytopathologica, v. 42, n. 4), p. 308-312, 2016. Disponível em: <https://dx.doi.org/10.1590/0100-5405/2116>.

HARPER, T. Dealing with soybean seedling diseases. Parsons: Farm Talk, 2012. Disponível em: $<$ http://farmtalknewspaper.com/crops/x915986154/Dealing-with-soybean-seedling-diseases>.

LENZ, G.; COSTA, I. D. da; BALARDIN, R. S.; MARQUES, L. N.; ARRUÉ, A.; STEFANELO, M. S.; ZEMOLIN, C. R. Elaboração e validação de escala diagramática para quantificação da mancha de isariopsis da videira. Ciência Rural, v.39, n.8, p.2301-2308, nov. 2009. Disponível em: $<\mathrm{http}: / /$ www.scielo.br/scielo.php?script=sci_arttext\&pid=S0103-84782009000800005>. Acesso em: 15 mar. 2009. https://doi.org/10.1590/S0103-84782009000800005

McKINNEY, H. H. Influence of soil, temperature and moisture on infection of wheat seedlings by Helminthosporium sativum. Journal of Agricultural Research, Washington, v.26, p.195-217, Nov. 1923.

MALVICK, D. Soybean seed and seedling diseases. Minneapolis: University of Minnesota, 2017. Disponível em:<http://www.extension.umn.edu/cropdiseases/soybean/soybeandisease.html>.

MARTINS, M. C.; GUERZONI, R. A.; CÂMARA, G. M. de S.; MATTIAZZI, P.; LOURENÇO, S. A.; AMORIM, L. Escala diagramática para quantificação do complexo de doenças foliares de final de ciclo em soja. Fitopatologia Brasileira, v.29, n. 2, p.179-184, Mar./Apr. 2004. Disponível em:<http://www.scielo.br/scielo.php?script=sci_arttext\&pid=S0100-41582004000200009\&lng=pt\&nrm=iso $>$.

MCLEAN, K.; GAZAWAY, W. Fungicides are worth the money: cotton seed disease management studies show fungicide use is effective for Alabama farmers. Highlights of Agricultural Research, v. 47, n. 2 , Summer 2000. Disponível em:

$<$ http://ag.auburn.edu/aaes/communications/highlights/summer00/fungicides.html>.

RIZVI, S. S. A.; YANG, X. B. Fungi associated with soybean seedling disease in Iowa. Plant Disease, v. 80, n.1, p. 57-60, Jan. 1996. https://doi.org/10.1094/PD-80-0057 
RODRIGUES, F. de Á.; CORRÊA, G. F.; KORNDÖRFER, G. H.; SANTOS, M. A. dos; DATNOFF, L. E. Efeito do silicato de cálcio e da autoclavagem na supressividade e na conducividade de dois solos à Rhizoctonia solani. Pesquisa Agropecuária Brasileira, v. 34, n. 8, p. 1367-1371, ago. 1999.

SARTORATO, A.; RAVA, C. A.; YOKOYAMA, M. Principais doenças e pragas do feijoeiro comum no Brasil. 3. ed. Goiânia: EMBRAPA-CNPAF, 1987. 53 p. (EMBRAPA-CNPAF. Documentos, 5).

VAN SCHOONHOVEN, A.; PASTOR-CORRALES, M. A. Standard system for the evaluation of bean germplasm. Cali. CIAT. 1987.

ZAMBOLIN, L.; COSTA, H.; VALE, F. X. R. Feijão Comum (Phaseolus vulgaris L.): Controle de doenças podridão, tombamento e murcha causados por fungos de solo. In: VALE, F. X. R. do; ZAMBOLIN, L. (Ed.). Controle de doenças de plantas: grandes culturas. Viçosa, MG: UFV Imprensa Universitária, 1997. v. 2, p. 375-402.

ZEUN, R.; SSCALLIET, G.; OOSTENDORP, M. Biological activity of sedaxane - a novel broad-spectrum fungicide for seed treatment. Pest Management Science, v. 69, n. 4, p. 527-534, 2013.

https://doi.org/10.1002/ps.3405 